\title{
REVIEW
}

\section{Polygenic Causes of Congenital Diaphragmatic Hernia Produce Common Lung Pathologies}

\author{
Patricia K. Donahoe, ${ }^{* \dagger \ddagger}$ Mauro Longoni, ${ }^{* \dagger}$ and Frances A. High ${ }^{* \dagger \delta \uparrow}$
}

From the Pediatric Surgical Research Laboratories* and the Department of Pediatrics, ${ }^{\S}$ Massachusetts General Hospital, Boston; the Department of Surgery, ${ }^{\dagger}$ Harvard Medical School, Boston; the Broad Institute of the Massachusetts Institute of Technology and Harvard, ${ }^{\ddagger}$ Cambridge; and the Department of Surgery, Boston Children's Hospital, Boston, Massachusetts

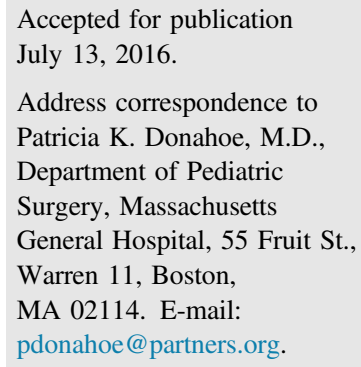

\begin{abstract}
Congenital diaphragmatic hernia $(\mathrm{CDH})$ is one of the most common and lethal congenital anomalies, and significant evidence is available in support of a genetic contribution to its etiology, including single-gene knockout mice associated with diaphragmatic defects, rare monogenetic disorders in humans, familial aggregation, and association of $\mathrm{CDH}$ with chromosomal abnormalities. Structural lung defects in the form of lung hypoplasia are almost invariably seen in patients with $\mathrm{CDH}$ and frequently in animal models of this condition. Better understanding of the mechanisms of pulmonary defects in $\mathrm{CDH}$ has the potential for creating targeted therapies, particularly in postnatal stages, when therapeutics can have maximum clinical impact on the surviving cohorts. Successful treatment of CDH is dependent on the integration of human genomic and genetic data with developmental expression profiling, mouse knockouts, and gene network and pathway modeling, which have generated a large number of candidate genes and pathways for follow-up studies. In particular, defective alveolarization appears to be a common and potentially actionable phenotype in both patients and animal models. (Am J Pathol 2016, 186: 2532-2543; http://dx.doi.org/10.1016/j.ajpath.2016.07.006)
\end{abstract}

\section{A Multimodal War on Congenital Diaphragmatic Hernia}

Congenital diaphragmatic hernia $(\mathrm{CDH})$ is a common and severe birth defect that affects 1:3000 live births. ${ }^{1,2}$ It is characterized by defective formation and/or muscularization of the diaphragm, often with displacement of abdominal contents into the chest cavity. CDH is almost invariably accompanied by pulmonary hypoplasia, which is the major cause of morbidity and mortality in patients and requires immediate and complex care. ${ }^{3}$ The clinical importance of $\mathrm{CDH}$ relates to its high frequency among birth defects, its severity, and the challenges related to its treatment, which is intense and expensive, placing a burden on the affected families and the health care system. Approximately $60 \%$ of cases are isolated defects that affect otherwise healthy term infants, indicating a good clinical prognosis if lung hypoplasia can be improved.
Significant progress has been made in the care of these patients in the past 2 decades, although mortality rates remain at $30 \%$ to $50 \%$ worldwide. ${ }^{1}$ Currently, the main therapeutic goal is to stabilize the cardiac and respiratory systems in infants with $\mathrm{CDH}$, while attempting to minimize iatrogenic (therapy-induced) injury to the delicate pulmonary tissue, before and after surgical repair of the diaphragm. Gentle ventilation techniques, high-frequency ventilation, cardiovascular pharmacologic support, and extracorporeal membrane oxygenation ${ }^{3-6}$ have improved survival rates, although these interventions have their own early and long-term complications. Lengthy and expensive

\footnotetext{
Supported by National Institute of Child Health and Human Development grant P01 HD068250-05 (P.K.D. and M.L.) and National Research Service Award 2T32GM007748-35 (F.A.H.).

This article is part of a review series on lung ontogeny and injury.

Disclosures: None declared.
} 
stays in neonatal intensive care units are often necessary. A significant number of infants still succumb to the pulmonary complications of $\mathrm{CDH}$, with late deaths mostly attributable to pulmonary hypertension and pulmonary insufficiency. Furthermore, many $\mathrm{CDH}$ survivors experience adverse long-term outcomes, including residual cardiopulmonary disease, neurodevelopmental defects, sensorineural hearing loss, and feeding difficulties. ${ }^{8-10}$

The lungs in infants with $\mathrm{CDH}$ have reduced volumes and weight with histologic features of developmental immaturity, manifested by a reduction in the number and size of alveoli. Several mechanisms have been hypothesized to cause $\mathrm{CDH}$-associated lung hypoplasia. Classic teaching indicated that compression of the lung by herniated viscera and the lack of respiratory movements were the root causes of the hypoplasia phenotype; however, other studies suggest that abnormal lung development precedes the herniation of abdominal contents into the thoracic cavity, and it is therefore a primary, not secondary, defect. ${ }^{11-13}$ These observations have led to the conclusion that the lung defects are at least partially independent of the diaphragm defect and pose many questions about what links the abnormalities of these two organs at the molecular or mechanistic level.

Whereas others have reviewed the embryology of the diaphragm, ${ }^{14}$ this review focuses on our current understanding of the mechanisms of pulmonary defects in $\mathrm{CDH}$ and on the potential for targeting postnatal stages of lung development, when therapeutics can have maximum clinical impact on the surviving cohorts.

\section{Overview of Diaphragm and Lung Development}

The diaphragm forms from multiple tissue sources, including transient embryonic structures of mesenchymal tissue that make up the septum transversum and pleuroperitoneal folds (PPFs). The muscles lying at the periphery of the diaphragm derive from migrating cells delaminating from the somitic dermatomyotome, which also contributes to the skeletal muscle of the limbs and body wall. ${ }^{15-18}$ The fundamental role of connective tissue in the PPFs was demonstrated by analysis of conditional Prxl-cre ${ }^{\mathrm{Tg} /+} ;$ Gata $^{\Delta / f l}$ mice, with complete Gata4 ablation in the lateral plate mesoderm-derived PPF cells. Abnormalities in the PPF connective tissue result in failure of migration and differentiation of muscle precursor cells, leading to subsequent hernia formation. ${ }^{19}$ Eighty percent of hernias occur in the left posterolateral diaphragm, begging the questions of why this position is so often targeted for mishap.

Development of the lungs is a complex, multistep process, and perturbation of any of these steps can lead to pulmonary defects (Figure 1). The process initiates with ventral budding from the ventral foregut endoderm. This lung bud then undergoes a process of elongation and branching morphogenesis, which follows a characteristic reproducible pattern based on the Fibonacci sequence, together with subsequent sequential multiplanar rotations that are regulated with a periodicity ${ }^{20}$ and is regulated by multiple pathways, including fibroblast growth factor, Wnt, sonic hedgehog, transforming growth factor- $\beta$, and bone

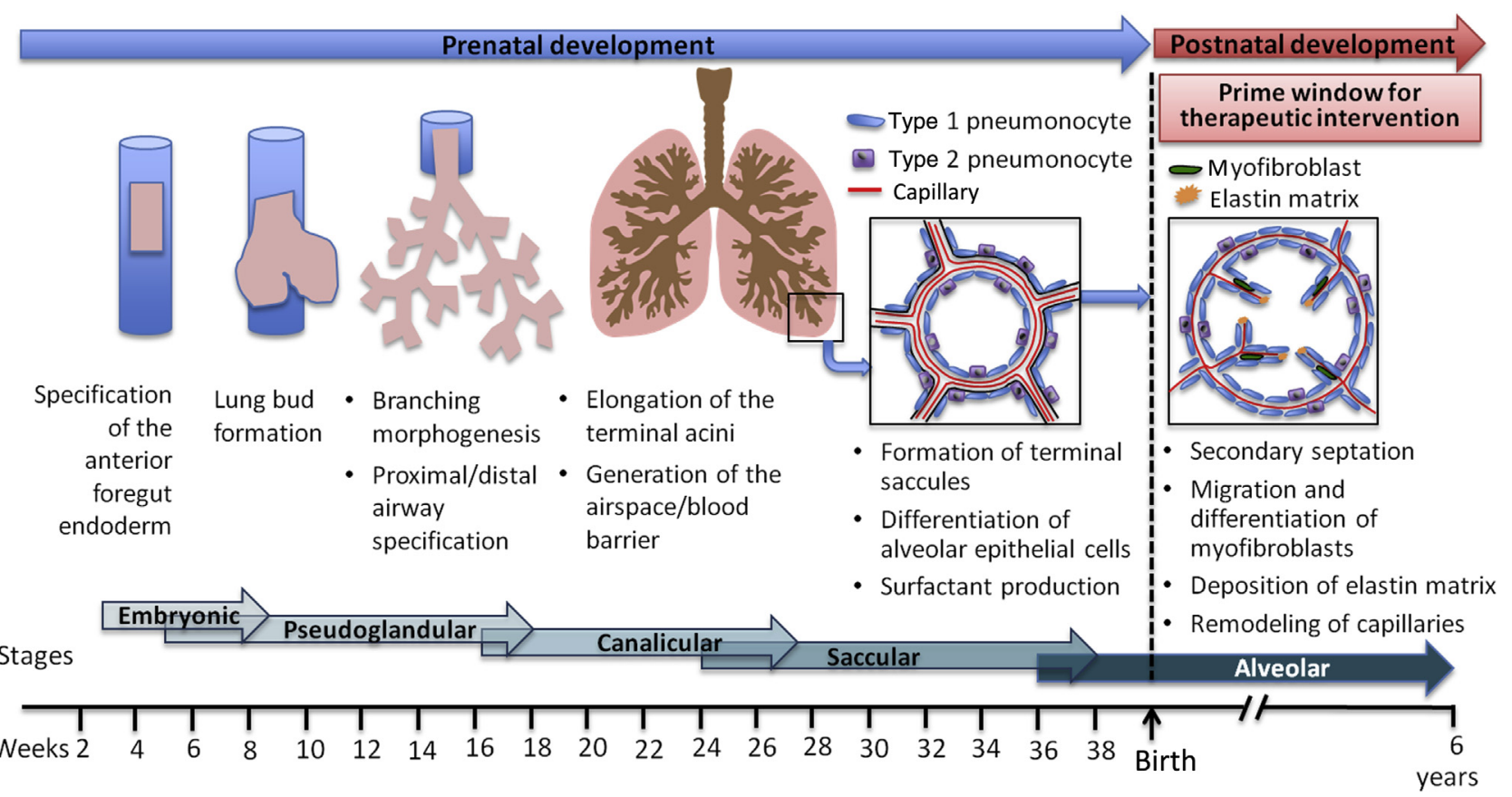

Figure 1 Timeline of pulmonary development. Human lung development is divided into prenatal and postnatal phases, separated by the dotted line indicating birth. Developmental stages are plotted against gestational weeks (below) and are divided into the partially overlapping embryonic, pseudoglandular, canalicular, saccular, and alveolar stages. Development of the alveolus continues with increased septation for several years during childhood. A number of $\mathrm{CDH}$-associated genes affect branching morphogenesis in the lungs, but alveolarization and vascular defects are also reported in patients with $\mathrm{CDH}$. The most practical window for therapeutic intervention is indicated by the pink box. 
morphogenetic protein. ${ }^{21-26}$ Primary buds undergo additional branching to form multiple distal tubules during the pseudoglandular stage, and the tubules elongate during the canalicular phase. In the later stages of lung development, the distal airways form the critical interface for gas exchange. During middle to late gestation, the lungs enter the saccular phase, where the distal airways form rudimentary saccules, and the airway epithelium begins to secrete surfactant.

The final stage of lung development, alveolarization, begins before birth and continues through the newborn period and much of childhood in humans, commensurate with overall body growth. During the first phase of alveolarization, known as primary septation, the airway saccules become thinner, bringing the airway epithelium in close contact with the lung vasculature, thereby forming a basic unit for gas exchange. Subsequently, the alveoli mature through the process of secondary septation, in which multiple septa grow inward from the walls of each alveolus. Each septum contains two epithelial layers with a central core that contains a single capillary and mesenchymal components that include myofibroblasts and elastin, as well as other extracellular matrix components. The migration and differentiation of myofibroblasts in the alveolar septa are critical, ${ }^{27}$ although it remains a poorly understood aspect of lung development, as does the formation of lipofibroblasts. ${ }^{28}$ The process of secondary septation greatly increases the surface area for gas exchange within the lung, and because it occurs immediately prenatally and continues postnatally, it provides an attractive target for designing therapeutic interventions for patients with $\mathrm{CDH}$ and other neonatal lung diseases (Figure 1).

\section{Pulmonary Hypoplasia and Alveolarization Defects in CDH}

The eponymous hernia or hole in the diaphragm is accompanied by lung hypoplasia and pulmonary hypertension whose severity determines early mortality or survival. The lungs in patients with $\mathrm{CDH}$ appear immature, with thickened alveolar walls and increased interstitial tissue, effectively resulting in reduced alveolar spaces and gas-exchange surface $\operatorname{area}^{29}$ (Figure 2). Incomplete pulmonary mesenchymal thinning attributable to defective apoptosis, rather than true immaturity, has been proposed as a mechanism based on cellular models. ${ }^{13,30}$

\section{Congenital Diaphragmatic Hernia Lung Abnormalities Alveolar Block}

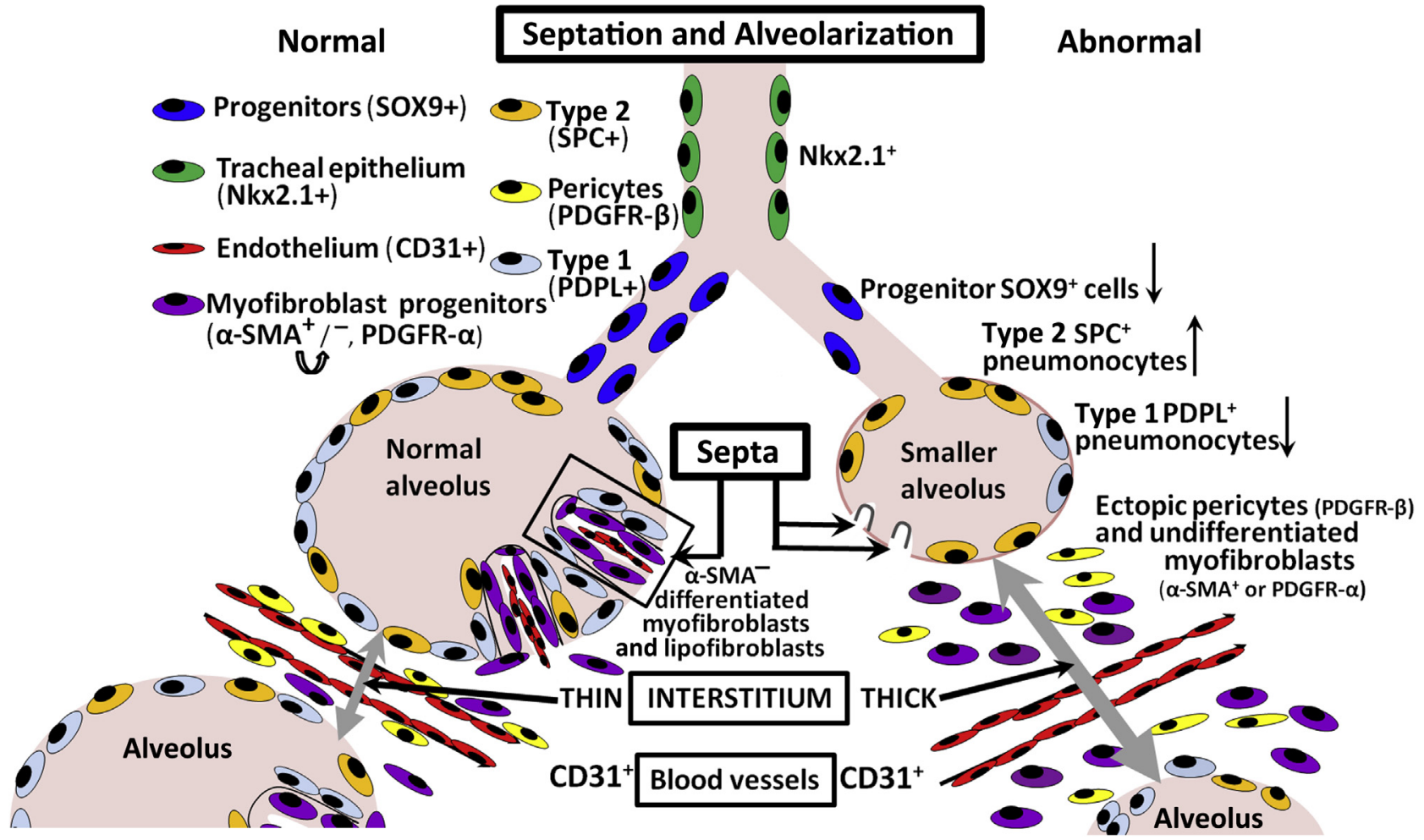

Figure $2 \mathrm{CDH}$ lung abnormalities. An alveolar block is hypothesized as a late phenotype in CDH, resulting in alveolar simplification. Smaller alveoli, lined by increased type 2 and reduced type 1 pneumocytes, contain stunted septa linked with defective myofibroblast proliferation and migration. Reduced Sox9positive progenitors indicate a defect in epithelial differentiation. The thickened interstitium suggests a delay in pulmonary maturation or abnormal resorption and results in poor oxygen exchange. $\alpha$-SMA, $\alpha$-smooth muscle actin; PDGFR, platelet-derived growth factor receptor; PDPL, podoplanin; SPC, surfactant protein $\mathrm{C}$. 
On a finer structural level, the lungs of patients with $\mathrm{CDH}$ are characterized by a failure to establish the necessary close association of the air-exposed epithelium to the abnormally differentiated and diminished mesenchymal vessels carrying the blood that must be oxygenated for survival. ${ }^{31,32}$ Failure of co-differentiation of the lung epithelium and mesenchymal compartment components can lead to insufficient gas exchange, the final common pathway of lethality in $\mathrm{CDH}$. This can result from mutations in any number of genes, each critical to the linear and parallel morphologic steps necessary to achieve a normally differentiated lung.

Much of our mechanistic understanding of the pulmonary defects in $\mathrm{CDH}$ has come from the study of animal models, particularly genetic models with both diaphragm and lung abnormalities (Table 1). ${ }^{33}$ In addition, surgical models on sheep and rabbits provide valuable information to study the mechanical effects of herniated viscera on the lung and to test interventional strategies, whereas the teratogenic nitrofen model mimics the human condition to a large extent, even though its applications are limited by the fact that nitrofen is not considered a cause of CDH in patients. ${ }^{34}$ Deficient alveolarization has been observed in $\mathrm{CDH}$, resulting from nitrofen administration, but can be improved by antenatal treatment with corticosteroids. ${ }^{35}$ Human studies have proven more challenging, likely because of pragmatic clinical difficulties in obtaining appropriate pathology specimens, because most infants with $\mathrm{CDH}$ undergo extensive ventilatory interventions that disrupt the natural architecture of the lung. Major bronchial subdivisions are normal in human autopsy specimens of hypoplastic CDH lungs; however, the number of intermediate bronchial branches is often reduced severely in the ipsilateral lung and less so in the contralateral lung, which comparatively maintains the potential of faster growth and complete differentiation during gestation. ${ }^{36,37}$ The prevalence of left-sided hernias suggests that left-right asymmetry may also be an important component of the pathophysiology of the hypoplasia.

Few of the extant alveoli have a normal structure. Pulmonary developmental studies of alveolarization assessed by such measures as mean linear intercepts and septal density $^{38-41}$ confirm that patients with $\mathrm{CDH}$ never achieve a full number of airway branches or spaces, despite the alveolar multiplication that occurs after birth. ${ }^{42,43}$ Vascular growth is even more compromised than alveolar growth. However, because alveolar maturation continues throughout infancy and childhood, there is a long actionable window during which to improve differentiation and pulmonary function in $\mathrm{CDH}$ survivors. The question is whether differentiation can be improved postnatally by targeting the developmental pathways found to be involved in the process of alveolarization.

Several homozygous knockout mouse models of CDH result in severe phenotypes with embryonic lethality. ${ }^{44,45}$ Many genes involved in the formation of the diaphragm are also likely to play important roles in the early stages of lung development (Table 1). Examples include ZFPM2 (FOG2) ${ }^{46}$ and members of the fibroblast growth factor signaling pathway, which result in pulmonary hypoplasia attributable to defects in branching morphogenesis. ${ }^{47,48}$ The effects of complete ablation of these early-acting genes in mice are especially severe and irreversible. ${ }^{32}$ However, the pathologic features in humans, who usually have only one nonfunctional copy of the gene, may be less severe and addressable in the immediate postnatal period. An increasing number of mouse models have implicated a role for $\mathrm{CDH}$ genes in the later stages of lung development, where early molecular correction or rescue can have potentially maximum clinical benefit and complications of barotrauma (eg, bronchopulmonary dysplasia and pulmonary fibrosis) are minimized or averted. $\mathrm{CDH}$ and bronchopulmonary dysplasia share structural and functional abnormalities in alveolar formation and pulmonary vasculature, possibly related to common disturbances in the retinoid acid pathway genes, ${ }^{49}$ which result in impaired gas exchange.

A complementary set of mammalian genetic, genomic, physiologic, and three-dimensional morphologic approaches have pointed to myofibroblasts and extracellular matrix constituents, such as elastin, as key players in these latestage CDH-associated pulmonary abnormalities. ${ }^{27,50}$ Lipofibroblasts, a lipid-containing population of interstitial fibroblasts first identified during the canalicular phase of lung development, were also reduced in rats treated with the CDH-inducing teratogen nitrofen. ${ }^{51,52}$ Lipofibroblast signaling is critical for the completion of alveologenesis, possibly in directing the production of surfactant phospholipids in type 2 pneumocytes. ${ }^{28}$

Pulmonary neuroendocrine cells (PNECs), detected by acetylcholine esterase staining in earlier studies, ${ }^{53,54}$ differentiate from distal progenitors and migrate proximally to form neuroepithelial bodies or clusters. Neuroepithelial bodies were reported to be increased in number and size in neonatal rats with diaphragmatic defects. ${ }^{55}$ The PNECproduced factors bombesin and ghrelin, which are likely to play important roles in lung development and regulating vascular tone, are expressed at higher levels in patients with $\mathrm{CDH} .{ }^{56} \mathrm{PNEC}$ clusters normally function in vivo as airway sensors for hypoxia, hypercarbia, and other toxic environmental changes. Excess secreted neuropeptides were linked to lung matrix remodeling and alveolar simplification or failure of septation, ${ }^{57}$ and PNEC factors have been proposed to sensitize the lungs to the effects of retinoic acid by regulating retinoic acid receptors $\alpha$ and $\gamma$ expression. ${ }^{58}$

\section{Pulmonary Hypertension in CDH}

In addition to the defective gas exchange mechanisms discussed above, another major contributor to the mortality of infants with $\mathrm{CDH}$ is pulmonary hypertension, which is characterized by abnormal endothelial and smooth muscle development, associated with failure of the vascular smooth muscle to relax normally after birth. ${ }^{59}$ The cause of pulmonary hypertension in patients with $\mathrm{CDH}$ is multifactorial, 
Table 1 Mouse Models with Both Diaphragm and Lung Abnormalities

\begin{tabular}{|c|c|c|c|}
\hline Symbol & Name & Diaphragmatic phenotype & Lung phenotype \\
\hline Atp2a1 & $\begin{array}{l}\text { ATPase, } \mathrm{Ca}^{++} \text {transporting, cardiac } \\
\text { muscle, fast twitch } 1\end{array}$ & Abnormal diaphragm muscle & $\begin{array}{l}\text { Abnormal alveoli (failure to expand, } \\
\text { hypercellularity) }\end{array}$ \\
\hline Ctnnb1 & $\begin{array}{l}\text { Catenin (cadherin associated protein), } \\
\quad \beta 1\end{array}$ & $\begin{array}{l}\text { Diaphragmatic hernia (Wt1-Cre } \\
\text { conditional knockout) }\end{array}$ & $\begin{array}{l}\text { Absent lung buds (Shh-Cre conditional } \\
\text { knockout) }\end{array}$ \\
\hline Efemp2 & $\begin{array}{l}\text { Epidermal growth factor-containing } \\
\text { fibulin-like extracellular matrix } \\
\text { protein } 2\end{array}$ & Diaphragmatic hernia & Abnormal elastic fibers \\
\hline Eya1 & $\begin{array}{l}\text { EYA transcriptional co-activator and } \\
\text { phosphatase } 1 \text { and } 2\end{array}$ & $\begin{array}{l}\text { Amuscular diaphragm (double Eya1; } \\
\text { Eya2 knockout) }\end{array}$ & $\begin{array}{l}\text { Lung hypoplasia, abnormal epithelium } \\
\text { morphologic features }\end{array}$ \\
\hline Eya2 & $\begin{array}{l}\text { EYA transcriptional co-activator and } \\
\text { phosphatase } 1 \text { and } 2\end{array}$ & $\begin{array}{l}\text { Amuscular diaphragm (double Eya1; } \\
\text { Eya2 knockout) }\end{array}$ & $\begin{array}{l}\text { Lung hypoplasia, abnormal epithelium } \\
\text { morphologic features }\end{array}$ \\
\hline Frem1 & $\begin{array}{l}\text { Fras1 related extracellular matrix } \\
\text { protein } 1\end{array}$ & Diaphragmatic hernia & Fused pulmonary lobes \\
\hline Frem2 & $\begin{array}{l}\text { Fras1-related extracellular matrix } \\
\text { protein } 2\end{array}$ & Diaphragmatic hernia & Fused pulmonary lobes \\
\hline Fuz & Fuzzy planar cell polarity protein & Diaphragmatic hernia & Lung hypoplasia \\
\hline Gata4 & GATA-binding protein 4 & Diaphragmatic hernia & $\begin{array}{l}\text { Abnormal saccule morphologic } \\
\text { features, abnormal vasculature }\end{array}$ \\
\hline Gli2, Gli3 & GLI-Kruppel family member 2 and 3 & $\begin{array}{l}\text { Diaphragmatic hernia (double Gli2; } \\
\text { Gli3 knockout) }\end{array}$ & $\begin{array}{l}\text { Lung hypoplasia, absent right lung } \\
\text { accessory lobe, thick mesenchyme }\end{array}$ \\
\hline$H L x$ & H2.0-like homeobox & Diaphragmatic hernia & Enlarged lungs with normal structure \\
\hline Igf2 & Insulin-like growth factor 2 & $\begin{array}{l}\text { Thin diaphragm muscle (double Igf2; } \\
\text { Myod1 knockout) }\end{array}$ & $\begin{array}{l}\text { Abnormal epithelial proliferation/ } \\
\text { differentiation (organ culture) }\end{array}$ \\
\hline Kif7 & Kinesin family member 7 & $\begin{array}{l}\text { Diaphragmatic hernia, thick diaphragm } \\
\text { muscle }\end{array}$ & Lung hypoplasia \\
\hline Lmnb1 & Lamin B1 & $\begin{array}{l}\text { Thin diaphragm muscle, abnormal } \\
\text { phrenic nerve }\end{array}$ & Abnormal alveoli \\
\hline Lmnb2 & Lamin B2 & $\begin{array}{l}\text { Thin diaphragm muscle, abnormal } \\
\text { phrenic nerve (double Lmnb1; } \\
\text { Lmnb2 knockout) }\end{array}$ & Abnormal alveoli \\
\hline Lox & Lysyl oxidase & $\begin{array}{l}\text { Diaphragmatic hernia, thin diaphragm } \\
\text { muscle }\end{array}$ & $\begin{array}{l}\text { Lung hypoplasia, abnormal acini, } \\
\text { abnormal elastic fibers }\end{array}$ \\
\hline Met & Met proto-oncogene & $\begin{array}{l}\text { Diaphragmatic hernia, thin diaphragm } \\
\text { muscle }\end{array}$ & $\begin{array}{l}\text { Abnormal saccule morphologic } \\
\text { features (conditional knockout } \\
\text { in the respiratory epithelium) }\end{array}$ \\
\hline Mmp2, Mmp14 & Matrix metallopeptidase 2, and 14 & $\begin{array}{l}\text { Thin diaphragm muscle (double } \\
\text { Mmp14; Mmp2 knockout) }\end{array}$ & $\begin{array}{l}\text { Lung hypoplasia, abnormal alveoli, } \\
\text { dilated alveolar ducts, abnormal } \\
\text { elastic fibers }\end{array}$ \\
\hline Myod1 & Myogenic differentiation 1 & Thin diaphragm muscle (MyoD:mdx) & Pulmonary hypoplasia (MyoD:mdx) \\
\hline Myog & Myogenin & Thin diaphragm muscle & Lung hypoplasia \\
\hline Msc & Musculin & $\begin{array}{l}\text { Diaphragmatic hernia (double Msc; } \\
\text { Tcf21 knockout) }\end{array}$ & $\begin{array}{l}\text { Lung hypoplasia, abnormal branching, } \\
\text { abnormal vasculature }\end{array}$ \\
\hline Ndst1 & $\begin{array}{l}N \text {-deacetylase } / N \text {-sulfotransferase } \\
\text { (heparan glucosaminyl) } 1\end{array}$ & $\begin{array}{l}\text { Diaphragmatic hernia, thin diaphragm } \\
\text { muscle (conditional knockout) }\end{array}$ & $\begin{array}{l}\text { Lung hypoplasia, thick interalveolar } \\
\text { septa }\end{array}$ \\
\hline$P b \times 1$ & Pre-B-cell leukemia homeobox 1 & Diaphragmatic hernia & Lung hypoplasia \\
\hline Pdgfra & $\begin{array}{l}\text { Platelet-derived growth factor } \\
\text { receptor, } \alpha \text {-polypeptide }\end{array}$ & Diaphragmatic hernia & $\begin{array}{l}\text { Lung hypoplasia, abnormal alveoli, } \\
\text { increased cell proliferation }\end{array}$ \\
\hline Rara, Rarb & Retinoic acid receptor, $\alpha$ and $\beta$ & $\begin{array}{l}\text { Diaphragmatic hernia (double Rara; } \\
\text { Rarb knockout) }\end{array}$ & $\begin{array}{l}\text { Lung hypoplasia, abnormal alveoli } \\
\text { (double Rara; Rarb knockout) }\end{array}$ \\
\hline Robo1, Robo 2 & Roundabout guidance receptor 1 & $\begin{array}{l}\text { Diaphragmatic hernia (double Robo1; } \\
\text { Robo2 knockout) }\end{array}$ & Abnormal alveoli, thick septa \\
\hline Six1 & $\begin{array}{l}\text { Sine oculis homeobox, Drosophila, } \\
\text { homolog of, } 1\end{array}$ & $\begin{array}{l}\text { Amuscular diaphragm (double Six1; } \\
\text { Six4 knockout) }\end{array}$ & Lung hypoplasia \\
\hline Tcf21 & Transcription factor 21 & $\begin{array}{l}\text { Diaphragmatic hernia (double Msc; } \\
\text { Tcf21 knockout) }\end{array}$ & $\begin{array}{l}\text { Lung hypoplasia, abnormal branching, } \\
\text { abnormal vasculature }\end{array}$ \\
\hline Wdr35 & WD repeat domain 35 & Diaphragmatic hernia & Pulmonary hypoplasia \\
\hline Wt1 & Wilms tumor 1 homolog & Diaphragmatic hernia & Lung hypoplasia \\
\hline Zfpm2 & Zinc finger protein, multitype 2 & $\begin{array}{l}\text { Abnormal diaphragm morphologic } \\
\text { features }\end{array}$ & $\begin{array}{l}\text { Lung hypoplasia, absent right lung } \\
\text { accessory lobe }\end{array}$ \\
\hline
\end{tabular}

The Mouse Genome Database Group 2015. ${ }^{33}$ 
with defects that affect lung vessel number and size. Autopsy specimens from patients with $\mathrm{CDH}$ reveal that lung vessel density is decreased. ${ }^{59}$ Also characteristic are the reduced complexity of proximal pulmonary artery branching and the paucity of microvascular or capillary networks, which should occur in parallel to the alveolarization of the distal lung. Diminished lung vessel size is also accompanied in patients by malposition and hypertrophy of vascular smooth muscle, as well as failure of the vascular smooth muscle to respond by relaxation in response to physiologic oxygen or nitrogen levels present at birth, compounded to the reduced response to treatment. It is unclear which of these abnormalities is the major contributing factor to pulmonary hypertension in patients with $\mathrm{CDH}$.

Genomic studies have found little overlap with gene mutations seen in hereditary forms of primary pulmonary hypertension, suggesting that $\mathrm{CDH}$-associated lung hypertension is likely dependent partially on different pathophysiologic mechanisms. ${ }^{60}$ Pulmonary antihypertensive therapy with inhaled nitric oxide or the use of phosphodiesterase inhibitors is suboptimal in patients with $\mathrm{CDH},{ }^{61}$ as has been the use of phosphodiesterase inhibitors attempted in clinical practice. In fact, no current pharmacologic regimen improves the pulmonary hypertension associated with $\mathrm{CDH}^{3,}{ }^{3,62}$ Improved understanding of how genetic defects contribute to $\mathrm{CDH}$-associated lung pathologies may lead to the discovery of pathways that affect alveolar septation and pulmonary vascular hemodynamics. This will help generate more accurate models of the pulmonary and vascular pathophysiology associated with $\mathrm{CDH}$ and ultimately improve short-term survival and ameliorate longterm morbidity.

\section{Genomic Studies in CDH}

Genetic studies on patients with $\mathrm{CDH}$ are providing important insight into the molecular mechanisms of both diaphragm and lung development. Several observations point toward genetic causation in CDH. ${ }^{1,2,63-66}$ Because of the clinical burden of $\mathrm{CDH}$, we and others have invested in genetic studies of rare families with mendelian patterns of inheritance $^{67-71}$ and of large patient cohorts. ${ }^{68,72}$

Familial studies revealed monogenic causes of $\mathrm{CDH}$, including the critical CDH genes ZFPM2 or FOG2, ${ }^{69,73}$ GATA4, ${ }^{71}$ and GATA6. $^{70}$ These families are rare, in part because of the early high mortality and reproductive disadvantage in $\mathrm{CDH}$. This is particularly true in complex CDH cases, which make up approximately $40 \%$ of all CDH cases. Isolated $\mathrm{CDH}(60 \%)$, without additional birth defects, can be familial, but pedigrees can be difficult to recognize because of reduced penetrance. ${ }^{69,71}$ On the other hand, systematic analysis of pedigrees contained in the Utah Population Database revealed distantly related patients with shared genomic regions from several extended families characterized by a high incidence of isolated $\mathrm{CDH},{ }^{74}$ supporting the notion of heritability in isolated $\mathrm{CDH}$.
$\mathrm{CDH}$ with associated lung hypoplasia and pulmonary hypertension is seen in a number of complex monogenic syndromes, including LRP2 (Donnai-Barrow syndrome), ${ }^{75}$ CHD7 (CHARGE syndrome), ${ }^{76}$ STRA6 (Matthew-Wood syndrome), ${ }^{77}$ GPC6 (Simpson-Golabi-Behmel syndrome), ${ }^{78}$ and NIPBL (Cornelia de Lange syndrome), ${ }^{79}$ among others. ${ }^{66,80}$ The importance of these genes is illustrated by the fact that we identified heterozygous predicted pathogenic variants, possibly risk alleles, in these genes in patients with both isolated and complex $\mathrm{CDH}^{68}$

Copy number variation studies using array-based comparative genome hybridization have allowed for more detailed delineation of chromosome regions and have provided higher resolution to detect smaller deletions and duplications. ${ }^{81,82} \mathrm{In}$ addition, recurrent chromosomal anomalies have been described in association with human $\mathrm{CDH}$ cases, and these have pointed toward several known and putative $\mathrm{CDH}$ genes. Chromosome studies identified several recurrent deletions in patients with $\mathrm{CDH}$, so-called hotspots, including 1q41-42, 8p23.1, and $15 \mathrm{q} 26^{83-87}$

Recently, next-generation sequencing technology, including whole exome sequencing and whole genome sequencing, allowed detection of single-nucleotide variants; however, the major challenge is how to prioritize the overwhelming number of potentially damaging variants that are detected. ${ }^{68,72}$ Bioinformatics can be used to enhance interpretation of individual gene variants by identifying their participation in molecular pathways and by documenting normal gene expression in the developing diaphragms and lungs, first in wild-type mice, ${ }^{88}$ then in mutant mice, and eventually in diaphragms of patients with $\mathrm{CDH}$ for comparison. The underlying hypothesis of these systems biology approaches is that $\mathrm{CDH}$ causative genes, however disparate, will fall into a limited number of key developmental pathways, ${ }^{68,88-90}$ as exemplified in a recent study of a cohort of 275 patients with $\mathrm{CDH}$ by whole exome sequencing. ${ }^{68}$

\section{Mouse Models of CDH and Lung Hypoplasia}

Because diaphragm and lung development in the mouse closely parallels that of the human, mouse models have played an invaluable role in enhancing our understanding of the genetic mechanisms underlying $\mathrm{CDH}$ and $\mathrm{CDH}-$ associated lung disease. To date, $>70$ genes have been found to cause diaphragm defects in existing mouse models, many of which have comorbid lung hypoplasia ${ }^{63,91}$ (Table 1). Many of these critical genes, discovered by mouse models, were later found to harbor rare and predicted pathogenic mutations in patients with $\mathrm{CDH}$, thereby implicating these genes in human $\mathrm{CDH}{ }^{68}$

Unbiased genetics screens can be used to identify further genes that cause $\mathrm{CDH}$ and lung defects, for example, through such approaches as the second phase of the Knockout Mouse Project, a multi-institutional initiative to produce a knockout for every known protein-coding gene in 
the mouse genome. ${ }^{92,93}$ Gross phenotyping of pups and adults can be supplemented by high-throughput screening of animal repositories by X-ray microtomography for identifying diaphragm defects in embryonic lethal strains. ${ }^{94}$

Globally, mouse models have been useful for the characterization of developmental mechanisms (Mouse Genome Informatics, http://www.informatics.jax.org, last accessed February 2016) and provide models for future in vivo rescue experiments after drug discovery screens. CRISPR/Cas9mediated genome editing has been useful in enhancing the efficiency and specificity of generating targeted mutations in mice. ${ }^{95-98}$ When coupled with Cre-directed strategies, ${ }^{27}$ it has been possible to dissect tissue- and cell-specific roles (eg, epithelial versus mesenchymal) for each gene in the developing lung.

\section{Studies of Alveolar Septation in CDH Models}

$\mathrm{CDH}$ lungs have aberrant morphologic features characterized by reduced radial alveolar count and thicker alveolar septa. Defective morphogenesis of the distal lung in the form of alveolar simplification is common. ${ }^{99,100}$ Late creation of the hernia in surgical models can produce alveolar hypoplasia without obvious branching defects. ${ }^{101}$

A number of mechanisms have been hypothesized to lead to abnormal septation in these models. Epithelial and endothelial approximation, often referred to as blood-gas barrier, is the functional unit of the alveoli, and collagens together with other extracellular matrix proteins are the major components of the basement membranes that support the architecture and function of the epithelium and endothelium. Reduced elastic fiber deposition may be responsible for the abnormal alveolar walls in patients with $\mathrm{CDH},{ }^{102}$ more specifically, defects of secondary alveologenesis possibly linked to insufficient fibroblast growth factor-18 expression. ${ }^{103}$ Reduced tropoelastin and elastin fibers result in stunted secondary septa with immature alveolar myofibroblasts ectopically displaced into the lung interstitium, ${ }^{50,103}$ where they disrupt oxygen exchange. ${ }^{27}$ Because this phenotype mimics the pathologic findings in humans surviving with $\mathrm{CDH}$, it offers a good model in which to test for therapeutic rescue.

Although several techniques have been used to investigate postnatal lung development, few provide the means to study secondary alveolarization directly. In fact, advancements in our understanding of pediatric pulmonary pathophysiology have been hindered by the lack of reproducible in vitro models. To this end, Kelleher and colleagues ${ }^{104}$ developed an assay based on ex vivo organ culture of $\mathrm{P} 4$ murine lungs that overcomes the limitations of substrate diffusion by preinflating the organ with $0.4 \%$ low-melt agarose at $20-\mathrm{cm} \mathrm{H}_{2} \mathrm{O}$ pressure. Organ maturation progresses for up to 4 days in culture, maintaining alveolar architecture, histologic features, and morphometrics (septal density and mean linear intercept). Furthermore, this ex vivo model is amenable to experimental manipulations, which will be useful to validate candidates emerging from drug discovery.

\section{Developmental Expression Profiling}

A useful strategy that we and others have used to identify $\mathrm{CDH}$ candidate genes is to compare human genetic data against expression profiles of the developing diaphragm, with the assumption that genes expressed at high levels during development are most likely to cause disease. We generated gene expression profiles from laser dissected PPFs, the anlage of the primordial diaphragm, prominent at E11.5 to E12.5 in the mouse embryo. This study identified a group of genes highly expressed in the PPFs but downregulated in the mature and fully muscularized diaphragm. ${ }^{88}$ As proof of principle, we validated this approach by detecting the presence of diaphragm and lung defects in the mouse knockout of one of the prioritized gene candidates, $P b x I^{88}$; furthermore, pathogenic variants in its paralog gene $P b x 3$ were subsequently identified in exomes of a cohort of 275 patients with $\mathrm{CDH}$ while being absent in controls, ${ }^{68}$ thus adding credence to this integrative approach for identifying novel $\mathrm{CDH}$ genes. This developmental data set has also helped in the interpretation of de novo variants from sequencing studies in trios and familial cases. ${ }^{72}$

Because developmental gene expression profiling in the diaphragm has proven to be a useful tool for identifying $\mathrm{CDH}$ genes, the search for candidate genes is being expanded by examining genes expressed in the developing lung, ${ }^{105}$ with a focus on genes that play a role in the later stages of lung development that may be amenable to therapeutic intervention. ${ }^{104}$

In addition, RNA sequencing was used to elucidate mRNA and miRNA expression changes in nitrofen-induced rat hypoplastic lungs ${ }^{106}$ that are evident even before the diaphragmatic defect could be observed. KEGG pathway analysis of significantly differentially expressed transcripts suggested that Wnt, transforming growth factor- $\beta$ signaling, and retinol metabolism pathways are involved in nitrofeninduced hypoplastic lungs, whereas differentially expressed miRNAs appeared to mediate nitrofen-induced cell cycle arrest and inhibition of proliferation, as well as smooth muscle cell dysfunction. ${ }^{106}$ Furthermore, miR449a, which functions to control $M y c$-directed normal lung proliferation, was elevated in mouse and human $\mathrm{CDH}$ lungs. ${ }^{107}$

\section{Drug Discovery and Novel Therapeutic Approaches}

Human and animal genetics held the promise of uncovering novel therapeutic targets because current treatment options for infants with $\mathrm{CDH}$ are limited to supportive ventilatory care and surgical repair. Attempts to increase pulmonary function with the use of prenatal and perinatal glucocorticoids, surfactants, and a number of pulmonary vasodilators 
have not been entirely successful. ${ }^{3,62}$ In addition, the development of therapeutics for $\mathrm{CDH}$-associated lung hypoplasia and pulmonary hypertension has been hindered by lack of standardization in methods and validated outcomes in preclinical research. ${ }^{108}$

Recent experimental approaches in nitrofen-treated rats with simvastatin revealed improvement in lung-to-body weight ratios and lung parenchyma structure, ${ }^{109}$ with effects attributed to changes in the endothelin, nitric oxide, and bone morphogenic protein receptor type 2 signaling pathways, and activation of epithelial apoptosis for tissue remodeling. ${ }^{109}$

Fetal endotracheal occlusion ${ }^{110,111}$ was developed on the premise that increased intrapulmonary pressure would improve lung maturation. In the fetal endotracheal occlusion procedure, an inflatable balloon ${ }^{110,112,113}$ or, more recently, a dissolving gel bolus ${ }^{114}$ is inserted in the trachea of latestage fetuses. A fetal endotracheal occlusion study is currently recruiting patients with $\mathrm{CDH}$ in the United States (ClinicalTrials.gov identifier: NCT00881660), but the clinical utility of this procedure is still unclear. Stem cell therapy by transplantation of human amniotic fluid stem cells has also been attempted in fetal endotracheal occlusion rabbit models with promising effects on lung-to-body weight ratio, mean terminal bronchiole density, and interstitial thickness. ${ }^{115,116}$

Retinoid signaling defects have been associated with diaphragm abnormalities and lung defects. ${ }^{117}$ Because of its poorly understood therapeutic window, retinoids and their derivatives have been avoided in the treatment of $\mathrm{CDH}$ and its related complications. However, improved knowledge of the mechanism of action of retinoic acid in the developing lung, such as through its effect on PNECs, ${ }^{57,58}$ may revive its consideration as a treatment option. In fact, the PNEC-secreted hormone ghrelin alleviates the phenotype of pulmonary hypoplasia in a $\mathrm{CDH}$ animal model. ${ }^{118}$

Among molecules currently being tested for their ability to rescue the pulmonary phenotype of $\mathrm{CDH}$ is the glucagonlike peptide- 1 . When administered transplacentally in a surgically induced rabbit model, glucagon-like peptide-1 improved peripheral pulmonary vessel morphologic features without changes in alveolarization. However, its administration was associated with significant maternal and fetal adverse effects. ${ }^{119}$

Drug discovery should be designed to target the basic developmental processes of alveologenesis in mice with conditional knockouts and directed toward specific cell types in the developing lung as potential therapeutics to rescue animal models in vivo. Similar approaches can be used to uncover pharmacologic agents to correct vascular changes in $\mathrm{CDH}$-associated pulmonary hypertension and in the hyperoxia model of bronchopulmonary dysplasia. ${ }^{49}$ Molecules that have a successful outcome in vivo could be advanced, in due time, to the design and implementation of clinical trials. To this end, a clinical translational infrastructure already established to study the genetics of $\mathrm{CDH}$, through collaborative efforts among neonatal care centers in the United States and abroad in the form of multicenter consortia, can be used to conduct clinical trials and to carry forward promising candidates as effective therapies for wider use in the clinic.

\section{Acknowledgments}

We thank Xin Sun, Ph.D., David J. McCulley, M.D., Wendy Chung, M.D., Yufeng Shen, Ph.D., Maria Loscertales, Ph.D., Carol Bult, Ph.D., and Barbara R. Pober, M.D., for their intellectual input and helpful discussions; the physicians at MassGeneral Hospital for Children and Boston Children's Hospital: Terry L. Buchmiller, Catherine C. Chen, Daniel P. Doody, Dario O. Fauza, Steven J. Fishman, Allan M. Goldstein, Lewis B. Holmes, Tom Jaksic, Russell Jennings, Cassandra M. Kelleher, David Lawlor, Craig W. Lillehei, Peter T. Masiakos, David P. Mooney, Konstantinos Papadakis, Rafael V. Pieretti, Mark Puder, Daniel P. Ryan, Robert C. Shamberger, C. Jason Smithers, Joseph P. Vacanti, Christopher Weldon, and Jill Zalieckas for their care of the patients with $\mathrm{CDH}$ in our study; and the Association of Congenital Diaphragmatic Hernia Research, Awareness, and Support and Breath of Hope for their support of patients with $\mathrm{CDH}$.

\section{References}

1. Pober BR: Overview of epidemiology, genetics, birth defects, and chromosome abnormalities associated with CDH. Am J Med Genet C Semin Med Genet 2007, 145C:158-171

2. Pober BR: Genetic aspects of human congenital diaphragmatic hernia. Clin Genet 2008, 74:1-15

3. Stolar CJ, Dillon PW: Congenital Diaphragmatic Hernia and Eventration. Pediatric Surgery. ed 7. Philadelphia, Mosby, 2012, pp 809-824

4. Beaumier CK, Beres AL, Puligandla PS, Skarsgard ED; Canadian Pediatric Surgery Network: Clinical characteristics and outcomes of patients with right congenital diaphragmatic hernia: a populationbased study. J Pediatr Surg 2015, 50:731-733

5. Garcia AV, Thirumoorthi AS, Stolar CJH: Extracorporeal membrane oxygenation. Ashcraft's Pediatric Surgery, ed 6. London, New York: Saunders/Elsevier, 2014. pp. 83-93

6. Snoek KG, Capolupo I, van Rosmalen J, Hout LJ, Vijfhuize S, Greenough A, Wijnen RM, Tibboel D, Reiss IK; CDH Euro Consortium: Conventional mechanical ventilation versus highfrequency oscillatory ventilation for congenital diaphragmatic hernia: a randomized clinical trial (The VICI-trial). Ann Surg 2016, 263:867-874

7. Hayward MJ, Kharasch V, Sheils C, Friedman S, Dunleavy MJ, Utter S, Zurakowski D, Jennings R, Wilson JM: Predicting inadequate long-term lung development in children with congenital diaphragmatic hernia: an analysis of longitudinal changes in ventilation and perfusion. J Pediatr Surg 2007, 42:112-116

8. Amoils M, Crisham Janik M, Lustig LR: Patterns and predictors of sensorineural hearing loss in children with congenital diaphragmatic hernia. JAMA Otolaryngol Head Neck Surg 2015, 141:923-926

9. Danzer E, Gerdes M, D’Agostino JA, Bernbaum J, Hoffman C, Herkert LM, Rintoul NE, Peranteau WH, Flake AW, Adzick NS, Hedrick HL: Younger gestational age is associated with increased risk 
of adverse neurodevelopmental outcome during infancy in congenital diaphragmatic hernia. J Pediatr Surg 2016, 51:1084-1090

10. Snoek KG, Capolupo I, Braguglia A, Aite L, van Rosmalen J, Valfre L, Wijnen RM, Bagolan P, Tibboel D, IJsselstijn H: Neurodevelopmental outcome in high-risk congenital diaphragmatic hernia patients: an appeal for international standardization. Neonatology 2016, 109:14-21

11. Cilley RE, Zgleszewski SE, Krummel TM, Chinoy MR: Nitrofen dose-dependent gestational day-specific murine lung hypoplasia and left-sided diaphragmatic hernia. Am J Physiol 1997, 272: L362-L371

12. Jesudason EC, Connell MG, Fernig DG, Lloyd DA, Losty PD: Early lung malformations in congenital diaphragmatic hernia. J Pediatr Surg 2000, 35:124-127; discussion 8

13. Keijzer R, Liu J, Deimling J, Tibboel D, Post M: Dual-hit hypothesis explains pulmonary hypoplasia in the nitrofen model of congenital diaphragmatic hernia. Am J Pathol 2000, 156:1299-1306

14. Merrell AJ, Kardon G: Development of the diaphragm - a skeletal muscle essential for mammalian respiration. FEBS J 2013, 280: 4026-4035

15. Ackerman KG, Greer JJ: Development of the diaphragm and genetic mouse models of diaphragmatic defects. Am J Med Genet C Semin Med Genet 2007, 145C:109-116

16. Clugston RD, Greer JJ: Diaphragm development and congenital diaphragmatic hernia. Semin Pediatr Surg 2007, 16:94-100

17. Clugston RD, Zhang W, Greer JJ: Gene expression in the developing diaphragm: significance for congenital diaphragmatic hernia. Am J Physiol Lung Cell Mol Physiol 2008, 294:L665-L675

18. Clugston RD, Zhang W, Greer JJ: Early development of the primordial mammalian diaphragm and cellular mechanisms of nitrofeninduced congenital diaphragmatic hernia. Birth Defects Res A Clin Mol Teratol 2010, 88:15-24

19. Merrell AJ, Ellis BJ, Fox ZD, Lawson JA, Weiss JA, Kardon G: Muscle connective tissue controls development of the diaphragm and is a source of congenital diaphragmatic hernias. Nat Genet 2015, 47: 496-504

20. Metzger RJ, Klein OD, Martin GR, Krasnow MA: The branching programme of mouse lung development. Nature 2008, 453: $745-750$

21. Cardoso WV, Lu J: Regulation of early lung morphogenesis: questions, facts and controversies. Development 2006, 133:1611-1624

22. El-Bizri N, Wang L, Merklinger SL, Guignabert C, Desai T, Urashima T, Sheikh AY, Knutsen RH, Mecham RP, Mishina Y, Rabinovitch M: Smooth muscle protein 22alpha-mediated patchy deletion of Bmprla impairs cardiac contractility but protects against pulmonary vascular remodeling. Circ Res 2008, 102:380-388

23. Guzy RD, Stoilov I, Elton TJ, Mecham RP, Ornitz DM: Fibroblast growth factor 2 is required for epithelial recovery, but not for pulmonary fibrosis, in response to bleomycin. Am J Respir Cell Mol Biol 2015, 52:116-128

24. Hogan BL, Kolodziej PA: Organogenesis: molecular mechanisms of tubulogenesis. Nat Rev Genet 2002, 3:513-523

25. Ritty TM, Broekelmann TJ, Werneck CC, Mecham RP: Fibrillin-1 and -2 contain heparin-binding sites important for matrix deposition and that support cell attachment. Biochem J 2003, 375:425-432

26. Sicot FX, Tsuda T, Markova D, Klement JF, Arita M, Zhang RZ, Pan TC, Mecham RP, Birk DE, Chu ML: Fibulin-2 is dispensable for mouse development and elastic fiber formation. Mol Cell Biol 2008, 28:1061-1067

27. Branchfield K, Li R, Lungova V, Verheyden JM, McCulley D, Sun X: A three-dimensional study of alveologenesis in mouse lung. Dev Biol 2016, 409:429-441

28. McGowan SE, Torday JS: The pulmonary lipofibroblast (lipid interstitial cell) and its contributions to alveolar development. Annu Rev Physiol 1997, 59:43-62

29. Sluiter I, Veenma D, van Loenhout R, Rottier R, de Klein A, Keijzer R, Post M, Tibboel D: Etiological and pathogenic factors in congenital diaphragmatic hernia. Eur J Pediatr Surg 2012, 22: 345-354

30. van Loenhout RB, Tseu I, Fox EK, Huang Z, Tibboel D, Post M, Keijzer R: The pulmonary mesenchymal tissue layer is defective in an in vitro recombinant model of nitrofen-induced lung hypoplasia. Am J Pathol 2012, 180:48-60

31. Hislop A, Reid L: Pulmonary arterial development during childhood: branching pattern and structure. Thorax 1973, 28:129-135

32. Reid LM: Lung growth in health and disease. Br J Dis Chest 1984, 78:113-134

33. Eppig JT, Blake JA, Bult CJ, Kadin JA, Richardson JE; Mouse Genome Database Group: The Mouse Genome Database (MGD): facilitating mouse as a model for human biology and disease. Nucleic Acids Res 2015, 43:D726-D736

34. van Loenhout RB, Tibboel D, Post M, Keijzer R: Congenital diaphragmatic hernia: comparison of animal models and relevance to the human situation. Neonatology 2009, 96:137-149

35. Suen HC, Bloch KD, Donahoe PK: Antenatal glucocorticoid corrects pulmonary immaturity in experimentally induced congenital diaphragmatic hernia in rats. Pediatr Res 1994, 35:523-529

36. Coleman A, Phithakwatchara N, Shaaban A, Keswani S, KlineFath B, Kingma P, Haberman B, Lim FY: Fetal lung growth represented by longitudinal changes in MRI-derived fetal lung volume parameters predicts survival in isolated left-sided congenital diaphragmatic hernia. Prenat Diagn 2015, 35:160-166

37. Phithakwatchara N, Coleman A, Peiro JL, Lee AE, Keswani SG, Kline-Fath B, Lim FY, Shaaban AF: Expanded intrathoracic space in fetal cases of isolated congenital diaphragmatic hernia contributes to disparity between percent predicted lung volume and observed to expected total lung volume. Prenat Diagn 2015, 35:154-159

38. Hsia CC, Hyde DM, Ochs M, Weibel ER; ATS/ERS Joint Task Force on Quantitative Assessment of Lung Structure: An official research policy statement of the American Thoracic Society/European Respiratory Society: standards for quantitative assessment of lung structure. Am J Respir Crit Care Med 2010, 181:394-418

39. Tschanz SA, Burri PH: A new approach to detect structural differences in lung parenchyma using digital image analysis. Exp Lung Res 2002, 28:457-471

40. Weibel ER: Principles and methods for the morphometric study of the lung and other organs. Lab Invest 1963, 12:131-155

41. Weibel ER: Morphometry of the Human Lung. New York, NY, Academic Press, 1963

42. Bachiller PR, Nakanishi H, Roberts JD Jr: Transforming growth factor-beta modulates the expression of nitric oxide signaling enzymes in the injured developing lung and in vascular smooth muscle cells. Am J Physiol Lung Cell Mol Physiol 2010, 298:L324-L334

43. Nakanishi H, Sugiura T, Streisand JB, Lonning SM, Roberts JD Jr: TGF-beta-neutralizing antibodies improve pulmonary alveologenesis and vasculogenesis in the injured newborn lung. Am J Physiol Lung Cell Mol Physiol 2007, 293:L151-L161

44. Beurskens N, Klaassens M, Rottier R, de Klein A, Tibboel D: Linking animal models to human congenital diaphragmatic hernia. Birth Defects Res A Clin Mol Teratol 2007, 79:565-572

45. Chiu PP: New insights into congenital diaphragmatic hernia - a surgeon's introduction to CDH animal models. Front Pediatr 2014, 2:36

46. Ackerman KG, Herron BJ, Vargas SO, Huang H, Tevosian SG, Kochilas L, Rao C, Pober BR, Babiuk RP, Epstein JA, Greer JJ, Beier DR: Fog2 is required for normal diaphragm and lung development in mice and humans. PLoS Genet 2005, 1:58-65

47. Friedmacher F, Doi T, Gosemann JH, Fujiwara N, Kutasy B, Puri P: Upregulation of fibroblast growth factor receptor 2 and 3 in the late stages of fetal lung development in the nitrofen rat model. Pediatr Surg Int 2012, 28:195-199

48. Friedmacher F, Gosemann JH, Fujiwara N, Takahashi H, Hofmann A, Puri P: Expression of Sproutys and SPREDs is decreased during lung branching morphogenesis in nitrofen-induced pulmonary hypoplasia. Pediatr Surg Int 2013, 29:1193-1198 
49. Silva DM, Nardiello C, Pozarska A, Morty RE: Recent advances in the mechanisms of lung alveolarization and the pathogenesis of bronchopulmonary dysplasia. Am J Physiol Lung Cell Mol Physiol 2015, 309:L1239-L1272

50. Loscertales M, Nicolaou F, Jeanne M, Longoni M, Gould DB, Sun Y, Maalouf FI, Nagy N, Donahoe PK: Type IV collagen drives alveolar epithelial-endothelial association and the morphogenetic movements of septation. BMC Biol 2016, 14:59

51. Friedmacher F, Fujiwara N, Hofmann AD, Takahashi H, Alvarez LA, Gosemann JH, Puri P: Prenatal retinoic acid increases lipofibroblast expression in hypoplastic rat lungs with experimental congenital diaphragmatic hernia. J Pediatr Surg 2014, 49:876-881; discussion 81

52. Friedmacher F, Fujiwara N, Hofmann AD, Takahashi $H$, Gosemann JH, Puri P: Evidence for decreased lipofibroblast expression in hypoplastic rat lungs with congenital diaphragmatic hernia. Pediatr Surg Int 2014, 30:1023-1029

53. El-Bermani AW, Chang TL: Cobalt iontophoresis of sensory nerves in the rat lung. Am J Anat 1979, 154:277-281

54. Morikawa Y, Donahoe PK, Hendren WH: Cholinergic nerve development in fetal lung. Dev Biol 1978, 65:541-546

55. IJsselstijn H, Perrin DG, de Jongste JC, Cutz E, Tibboel D: Pulmonary neuroendocrine cells in neonatal rats with congenital diaphragmatic hernia. J Pediatr Surg 1995, 30:413-415

56. Asabe K, Tsuji K, Handa N, Kajiwara M, Suita S: Immunohistochemical distribution of bombesin-positive pulmonary neuroendocrine cells in a congenital diaphragmatic hernia. Surg Today 1999, 29:407-412

57. Branchfield K, Nantie L, Verheyden JM, Sui P, Wienhold MD, Sun X: Pulmonary neuroendocrine cells function as airway sensors to control lung immune response. Science 2016, 351:707-710

58. Pereira-Terra P, Moura RS, Nogueira-Silva C, Correia-Pinto J: Neuroendocrine factors regulate retinoic acid receptors in normal and hypoplastic lung development. J Physiol 2015, 593:3301-3311

59. Mohseni-Bod H, Bohn D: Pulmonary hypertension in congenital diaphragmatic hernia. Semin Pediatr Surg 2007, 16:126-133

60. Best DH, Austin ED, Chung WK, Elliott CG: Genetics of pulmonary hypertension. Curr Opin Cardiol 2014, 29:520-527

61. Finer NN, Barrington KJ: Nitric oxide for respiratory failure in infants born at or near term. Cochrane Database Syst Rev 2006:CD000399

62. Tsao KJ, Lally KP: Congenital diaphragmatic hernia and eventration. Ashcraft's Pediatric Surgery, ed 6. London, UK: Elsevier, 2014. pp. $315-340$

63. Brady PD, Srisupundit K, Devriendt K, Fryns JP, Deprest JA, Vermeesch JR: Recent developments in the genetic factors underlying congenital diaphragmatic hernia. Fetal Diagn Ther 2011, 29:25-39

64. Slavotinek AM: The genetics of common disorders - congenital diaphragmatic hernia. Eur J Med Genet 2014, 57:418-423

65. Veenma DC, de Klein A, Tibboel D: Developmental and genetic aspects of congenital diaphragmatic hernia. Pediatr Pulmonol 2012, 47:534-545

66. Wynn J, Yu L, Chung WK: Genetic causes of congenital diaphragmatic hernia. Semin Fetal Neonatal Med 2014, 19:324-330

67. Kantarci S, Ackerman KG, Russell MK, Longoni M, Sougnez C, Noonan KM, Hatchwell E, Zhang X, Pieretti Vanmarcke R, AnyaneYeboa K, Dickman P, Wilson J, Donahoe PK, Pober BR: Characterization of the chromosome $1 \mathrm{q} 41 \mathrm{q} 42.12$ region, and the candidate gene DISP1, in patients with CDH. Am J Med Genet A 2010, 152A: 2493-2504

68. Longoni M, High FA, Russell MK, Kashani A, Tracy AA, Coletti CM, Hila R, Shamia A, Wells J, Ackerman KG, Wilson JM, Bult CJ, Lee C, Lage K, Pober BR, Donahoe PK: Molecular pathogenesis of congenital diaphragmatic hernia revealed by exome sequencing, developmental data, and bioinformatics. Proc Natl Acad Sci U S A 2014, 111:12450-12455

69. Longoni M, Russell MK, High FA, Darvishi K, Maalouf FI, Kashani A, Tracy AA, Coletti CM, Loscertales M, Lage K, Ackerman KG, Woods SA, Ward-Melver C, Andrews D, Lee C,
Pober BR, Donahoe PK: Prevalence and penetrance of ZFPM2 mutations and deletions causing congenital diaphragmatic hernia. Clin Genet 2015, 87:362-367

70. Yu L, Bennett JT, Wynn J, Carvill GL, Cheung YH, Shen Y, Mychaliska GB, Azarow KS, Crombleholme TM, Chung DH, Potoka D, Warner BW, Bucher B, Lim FY, Pietsch J, Stolar C, Aspelund G, Arkovitz MS; University of Washington Center for Mendelian Genomics, Mefford H, Chung WK: Whole exome sequencing identifies de novo mutations in GATA6 associated with congenital diaphragmatic hernia. J Med Genet 2014, 51:197-202

71. Yu L, Wynn J, Cheung YH, Shen Y, Mychaliska GB, Crombleholme TM, Azarow KS, Lim FY, Chung DH, Potoka D, Warner BW, Bucher B, Stolar C, Aspelund G, Arkovitz MS, Chung WK: Variants in GATA4 are a rare cause of familial and sporadic congenital diaphragmatic hernia. Hum Genet 2013, 132:285-292

72. Yu L, Sawle AD, Wynn J, Aspelund G, Stolar CJ, Arkovitz MS, Potoka D, Azarow KS, Mychaliska GB, Shen Y, Chung WK: Increased burden of de novo predicted deleterious variants in complex congenital diaphragmatic hernia. Hum Mol Genet 2015, 24: 4764-4773

73. Brady PD, Van Houdt J, Callewaert B, Deprest J, Devriendt K, Vermeesch JR: Exome sequencing identifies ZFPM2 as a cause of familial isolated congenital diaphragmatic hernia and possibly cardiovascular malformations. Eur J Med Genet 2014, 57:247-252

74. Arrington CB, Bleyl SB, Matsunami N, Bowles NE, Leppert TI, Demarest BL, Osborne K, Yoder BA, Byrne JL, Schiffman JD, Null DM, DiGeronimo R, Rollins M, Faix R, Comstock J, Camp NJ, Leppert MF, Yost HJ, Brunelli L: A family-based paradigm to identify candidate chromosomal regions for isolated congenital diaphragmatic hernia. Am J Med Genet A 2012, 158A:3137-3147

75. Kantarci S, Al-Gazali L, Hill RS, Donnai D, Black GC, Bieth E, Chassaing N, Lacombe D, Devriendt K, Teebi A, Loscertales M, Robson C, Liu T, MacLaughlin DT, Noonan KM, Russell MK, Walsh CA, Donahoe PK, Pober BR: Mutations in LRP2, which encodes the multiligand receptor megalin, cause Donnai-Barrow and facio-oculo-acoustico-renal syndromes. Nat Genet 2007, 39:957-959

76. Vissers LE, van Ravenswaaij CM, Admiraal R, Hurst JA, de Vries BB, Janssen IM, van der Vliet WA, Huys EH, de Jong PJ, Hamel BC, Schoenmakers EF, Brunner HG, Veltman JA, van Kessel AG: Mutations in a new member of the chromodomain gene family cause CHARGE syndrome. Nat Genet 2004, 36:955-957

77. Golzio C, Martinovic-Bouriel J, Thomas S, Mougou-Zrelli S, Grattagliano-Bessieres B, Bonniere M, Delahaye S, Munnich A, EnchaRazavi F, Lyonnet S, Vekemans M, Attie-Bitach T, Etchevers HC: Matthew-Wood syndrome is caused by truncating mutations in the retinol-binding protein receptor gene STRA6. Am J Hum Genet 2007, 80:1179-1187

78. Paine-Saunders S, Viviano BL, Saunders S: GPC6, a novel member of the glypican gene family, encodes a product structurally related to GPC4 and is colocalized with GPC5 on human chromosome 13. Genomics 1999, 57:455-458

79. Krantz ID, McCallum J, DeScipio C, Kaur M, Gillis LA, Yaeger D, Jukofsky L, Wasserman N, Bottani A, Morris CA, Nowaczyk MJ, Toriello H, Bamshad MJ, Carey JC, Rappaport E, Kawauchi S, Lander AD, Calof AL, Li HH, Devoto M, Jackson LG: Cornelia de Lange syndrome is caused by mutations in NIPBL, the human homolog of Drosophila melanogaster Nipped-B. Nat Genet 2004, 36: 631-635

80. Pober BR, Russell MK, Ackerman KG: Congenital diaphragmatic hernia overview. In GeneReviews [Internet]. Copyright University of Washington, Seattle. 1993-2016. Available at http://www.ncbi.nlm. nih.gov/pubmed/20301533. (last revised March 16, 2010).

81. Iafrate AJ, Feuk L, Rivera MN, Listewnik ML, Donahoe PK, Qi Y, Scherer SW, Lee C: Detection of large-scale variation in the human genome. Nat Genet 2004, 36:949-951

82. Sebat J, Lakshmi B, Troge J, Alexander J, Young J, Lundin P, Maner S, Massa H, Walker M, Chi M, Navin N, Lucito R, Healy J, 
Hicks J, Ye K, Reiner A, Gilliam TC, Trask B, Patterson N, Zetterberg A, Wigler M: Large-scale copy number polymorphism in the human genome. Science 2004, 305:525-528

83. Borys D, Taxy JB: Congenital diaphragmatic hernia and chromosomal anomalies: autopsy study. Pediatr Dev Pathol 2004, 7:35-38

84. Klaassens M, van Dooren M, Eussen HJ, Douben H, den Dekker AT, Lee C, Donahoe PK, Galjaard RJ, Goemaere N, de Krijger RR, Wouters C, Wauters J, Oostra BA, Tibboel D, de Klein A: Congenital diaphragmatic hernia and chromosome 15q26: determination of a candidate region by use of fluorescent in situ hybridization and arraybased comparative genomic hybridization. Am J Hum Genet 2005, $76: 877-882$

85. Longoni $\mathrm{M}$, Lage $\mathrm{K}$, Russell MK, Loscertales M, AbdulRahman OA, Baynam G, Bleyl SB, Brady PD, Breckpot J, Chen CP, Devriendt K, Gillessen-Kaesbach G, Grix AW, Rope AF, Shimokawa O, Strauss B, Wieczorek D, Zackai EH, Coletti CM, Maalouf FI, Noonan KM, Park JH, Tracy AA, Lee C, Donahoe PK, Pober BR: Congenital diaphragmatic hernia interval on chromosome 8p23.1 characterized by genetics and protein interaction networks. Am J Med Genet A 2012, 158A:3148-3158

86. Srisupundit K, Brady PD, Devriendt K, Fryns JP, Cruz-Martinez R, Gratacos E, Deprest JA, Vermeesch JR: Targeted array comparative genomic hybridisation (array CGH) identifies genomic imbalances associated with isolated congenital diaphragmatic hernia $(\mathrm{CDH})$. Prenat Diagn 2010, 30:1198-1206

87. Wat MJ, Shchelochkov OA, Holder AM, Breman AM, Dagli A, Bacino C, Scaglia F, Zori RT, Cheung SW, Scott DA, Kang SH: Chromosome 8p23.1 deletions as a cause of complex congenital heart defects and diaphragmatic hernia. Am J Med Genet A 2009, 149A: $1661-1677$

88. Russell MK, Longoni M, Wells J, Maalouf FI, Tracy AA, Loscertales M, Ackerman KG, Pober BR, Lage K, Bult CJ, Donahoe PK: Congenital diaphragmatic hernia candidate genes derived from embryonic transcriptomes. Proc Natl Acad Sci U S A 2012, 109:2978-2983

89. Glessner JT, Bick AG, Ito K, Homsy JG, Rodriguez-Murillo L, Fromer M, Mazaika E, Vardarajan B, Italia M, Leipzig J, DePalma SR, Golhar R, Sanders SJ, Yamrom B, Ronemus M, Iossifov I, Willsey AJ, State MW, Kaltman JR, White PS, Shen Y, Warburton D, Brueckner M, Seidman C, Goldmuntz E, Gelb BD, Lifton R, Seidman J, Hakonarson H, Chung WK: Increased frequency of de novo copy number variants in congenital heart disease by integrative analysis of single nucleotide polymorphism array and exome sequence data. Circ Res 2014, 115:884-896

90. Naxerova K, Bult CJ, Peaston A, Fancher K, Knowles BB, Kasif S, Kohane IS: Analysis of gene expression in a developmental context emphasizes distinct biological leitmotifs in human cancers. Genome Biol 2008, 9:R108

91. Wilcox DT, Irish MS, Holm BA, Glick PL: Animal models in congenital diaphragmatic hernia. Clin Perinatol 1996, 23:813-822

92. Bradley A, Anastassiadis K, Ayadi A, Battey JF, Bell C, Birling MC, et al: The mammalian gene function resource: the International Knockout Mouse Consortium. Mamm Genome 2012, 23:580-586

93. International Mouse Knockout Consortium, Collins FS, Rossant J, Wurst W: A mouse for all reasons. Cell 2007, 128:9-13

94. Mallon AM, Iyer V, Melvin D, Morgan H, Parkinson H, Brown SD, Flicek P, Skarnes WC: Accessing data from the International Mouse Phenotyping Consortium: state of the art and future plans. Mamm Genome 2012, 23:641-652

95. Charpentier E, Doudna JA: Biotechnology: rewriting a genome. Nature 2013, 495:50-51

96. Cong L, Ran FA, Cox D, Lin S, Barretto R, Habib N, Hsu PD, Wu X, Jiang W, Marraffini LA, Zhang F: Multiplex genome engineering using CRISPR/Cas systems. Science 2013, 339:819-823

97. Iyer V, Shen B, Zhang W, Hodgkins A, Keane T, Huang X, Skarnes WC: Off-target mutations are rare in Cas9-modified mice. Nat Methods 2015, 12:479
98. Williams A, Henao-Mejia J, Flavell RA: Editing the mouse genome using the CRISPR-Cas9 system. Cold Spring Harb Protoc 2016, [Epub ahead of print] doi:10.1101/pdb.top087536

99. Nakamura Y, Harada K, Yamamoto I, Uemura Y, Okamoto K, Fukuda S, Hashimoto T: Human pulmonary hypoplasia: statistical, morphological, morphometric, and biochemical study. Arch Pathol Lab Med 1992, 116:635-642

100. Wigglesworth JS, Desai R, Guerrini P: Fetal lung hypoplasia: biochemical and structural variations and their possible significance. Arch Dis Child 1981, 56:606-615

101. Kent GM, Olley PM, Creighton RE, Dobbinson T, Bryan MH, Symchych P, Zingg W, Cummings JN: Hemodynamic and pulmonary changes following surgical creation of a diaphragmatic hernia in fetal lambs. Surgery 1972, 72:427-433

102. Nakamura Y, Fukuda S, Hashimoto T: Pulmonary elastic fibers in normal human development and in pathological conditions. Pediatr Pathol 1990, 10:689-706

103. Boucherat O, Benachi A, Barlier-Mur AM, Franco-Montoya ML, Martinovic J, Thebaud B, Chailley-Heu B, Bourbon JR: Decreased lung fibroblast growth factor 18 and elastin in human congenital diaphragmatic hernia and animal models. Am J Respir Crit Care Med 2007, 175:1066-1077

104. Pieretti AC, Ahmed AM, Roberts JD Jr, Kelleher CM: A novel in vitro model to study alveologenesis. Am J Respir Cell Mol Biol 2014, 50:459-469

105. Beauchemin KJ, Wells JM, Kho AT, Philip VM, Kamir D, Kohane IS, Graber JH, Bult CJ: Temporal dynamics of the developing lung transcriptome in three common inbred strains of laboratory mice reveals multiple stages of postnatal alveolar development. Peer J 2016, 4:e2318

106. Mahood TH, Johar DR, Iwasiow BM, Xu W, Keijzer R: The transcriptome of nitrofen-induced pulmonary hypoplasia in the rat model of congenital diaphragmatic hernia. Pediatr Res 2016, 79:766-775

107. Sanford EL, Choy KW, Donahoe PK, Tracy AA, Hila R, Loscertales M, Longoni M: MiR-449a affects epithelial proliferation during the pseudoglandular and canalicular phases of avian and mammal lung development. PLoS One 2016, 11:e0149425

108. Eastwood MP, Russo FM, Toelen J, Deprest J: Medical interventions to reverse pulmonary hypoplasia in the animal model of congenital diaphragmatic hernia: a systematic review. Pediatr Pulmonol 2015, 50:820-838

109. Makanga M, Maruyama H, Dewachter C, Da Costa AM, Hupkens E, de Medina G, Naeije R, Dewachter L: Prevention of pulmonary hypoplasia and pulmonary vascular remodeling by antenatal simvastatin treatment in nitrofen-induced congenital diaphragmatic hernia. Am J Physiol Lung Cell Mol Physiol 2015, 308:L672-L682

110. Deprest J, Gratacos E, Nicolaides KH, Group FT: Fetoscopic tracheal occlusion (FETO) for severe congenital diaphragmatic hernia: evolution of a technique and preliminary results. Ultrasound Obstet Gynecol 2004, 24:121-126

111. DiFiore JW, Fauza DO, Slavin R, Peters CA, Fackler JC, Wilson JM: Experimental fetal tracheal ligation reverses the structural and physiological effects of pulmonary hypoplasia in congenital diaphragmatic hernia. J Pediatr Surg 1994, 29:248-256; discussion 56-57

112. Al-Maary J, Eastwood MP, Russo FM, Deprest JA, Keijzer R: Fetal tracheal occlusion for severe pulmonary hypoplasia in isolated congenital diaphragmatic hernia: a systematic review and meta-analysis of survival. Ann Surg 2016, [Epub ahead of print] doi:10.1097/SLA. 0000000000001675

113. Sananes N, Rodo C, Peiro JL, Britto IS, Sangi-Haghpeykar H, Favre R, Joal A, Gaudineau A, Silva MM, Tannuri U, Zugaib M, Carreras E, Ruano R: Prematurity and fetal lung response after tracheal occlusion in fetuses with severe congenital diaphragmatic hernia. J Matern Fetal Neonatal Med 2016, 29:3030-3034

114. Elattal R, Rich BS, Harmon CM, Muensterer OJ: Pulmonary alveolar and vascular morphometry after gel plug occlusion of the trachea in a fetal rabbit model of CDH. Int J Surg 2013, 11:558-561 
115. DeKoninck P, Toelen J, Roubliova X, Carter S, Pozzobon M, Russo FM, Richter J, Vandersloten PJ, Verbeken E, De Coppi P, Deprest J: The use of human amniotic fluid stem cells as an adjunct to promote pulmonary development in a rabbit model for congenital diaphragmatic hernia. Prenat Diagn 2015, 35:833-840

116. Fauza DO: Tissue engineering in congenital diaphragmatic hernia. Semin Pediatr Surg 2014, 23:135-140

117. Noble BR, Babiuk RP, Clugston RD, Underhill TM, Sun H, Kawaguchi R, Walfish PG, Blomhoff R, Gundersen TE, Greer JJ: Mechanisms of action of the congenital diaphragmatic herniainducing teratogen nitrofen. Am J Physiol Lung Cell Mol Physiol 2007, 293:L1079-L1087
118. Santos M, Bastos P, Gonzaga S, Roriz JM, Baptista MJ, NogueiraSilva C, Melo-Rocha G, Henriques-Coelho T, RonconAlbuquerque R Jr, Leite-Moreira AF, De Krijger RR, Tibboel D, Rottier R, Correia-Pinto J: Ghrelin expression in human and rat fetal lungs and the effect of ghrelin administration in nitrofeninduced congenital diaphragmatic hernia. Pediatr Res 2006, 59: $531-537$

119. Eastwood MP, Kampmeijer A, Jimenez J, Zia S, Vanbree R, Verbist G, Toelen J, Deprest JA: The effect of transplacental administration of glucagon-like peptide-1 on fetal lung development in the rabbit model of congenital diaphragmatic hernia. Fetal Diagn Ther 2016, 39:125-133 